\title{
TAJO, JARAMA, AND GUADALQUIVIR RIVERS (SPAIN): COURT AND CITY - RECREATIONAL AND INDUSTRIAL ASPECTS OF THE RIVERS' COURSE
}

\author{
ELENA MARTÍNEZ SÁNCHEZ \& MIRIAM CAMPANARIO ORANTES \\ Polytechnic University of Madrid, Spain
}

\begin{abstract}
Rivers are key elements and sources of life: these are factors that have produced different scenarios through history and across various geographical environments. Three rivers have been considered as subject of study, which have created two different spaces allocated to industrial use and leisure. On the one hand, the Guadalquivir River, with a point of convergence of west Andalucía and which is the origin of important historical sites. Córdoba is located at the point where the river ceases to be navigable. Historically, this position has given this city the ability to dominate most of the communication routes in the south of the Iberian Peninsula. This made it possible to keep control of merchandise and people on the two sides of the river, and gave it the possibility of being the first city receiving products for commerce. This characteristic implies the use of the flows for industrial activity, such as constructing dams, water mills or flour mills along the course of the river. On the other hand, the Tajo and Jarama Rivers run through Aranjuez, in Madrid, and were modified to be given a leisure use by the Spanish Court. For this reason, several hydraulic engineering operations were developed, and consequently the courses were controlled by means of dams and canals. Both river flows were modified to provide two uses: the first one for commercial and industrial use, connecting the center of the peninsula through them. The second of these uses was recreational; fishing and navigation were developed in both rivers, and naumachias took place in an artificial sea constructed for its deployment.
\end{abstract}

Keywords: Tajo, Jarama, Guadalquivir, Córdoba, Aranjuez, rivers, water, cities, heritage.

\section{INTRODUCTION.}

Since ancient times, urban centers and rivers have dialogued with each other, exchanging natural and cultural values. The river was established as a determinant element, literal and symbolic, capable of ordering the territory and the landscape beyond its reference value. Of the enormous significance of the connection established by society is compounded by the fact of being able to connect elements of different nature that would appear unrelated without it.

The course of the river determines the position, growth and shape of settlements: floodplain, floods and the erosion of the fluvial course often pushed the cities to grow away from the river. The distance that the first settlements took from the shores would define the subsequent evolution of both, the urban layout and the use of the river.

The relationship between the city and its river would become increasingly complex depending on the risk of interventions on a larger or smaller scale according to the time, need and mentality that will be performed thus, those that we can observe at present have little or nothing to do with the origins.

In some cases, there may be a progressive deterioration of the city-river relationship: the very force of the water, which historically had a productive value, will lose its industrial purpose due to changes in production models. On the other hand, the shores would become marginal places instead of recreational areas. However, there may be also an evolution towards the opposite direction. 
The need to create defenses against floods such as dams, reservoirs and azures domesticated of the rivers, providing the opportunity to create riparian facades, influencing the city's urban planning, and locating free spaces for new infrastructures to arise.

Above all, the situations that may take place between the river and the city, the current study intends to focus only on the structuring aspects of the river: how to determine the form and the typology of the settlements along its banks, as well as the use of the flywheel course associated to each of them. For this publication, two completely different cases have been chosen: on the one hand, the city of Aranjuez and its evolution throughout the different uses that were given to the Tajo river and the use and enjoyment of the Spanish Royal Family, and on the other hand the city of Córdoba and the industrial use given to the Guadalquivir river in order to guarantee the survival of the urban areas.

\section{ARANJUEZ, TAJO AND JARAMA RIVERS}

Aranjuez is located in the South of Madrid, region the point where both rivers Tajo and Jarama converge; the point where they converge created a plain that along the centuries led to the foundation of the leisure house of the Order of Santiago which subsequently, it also led to the construction of the Royal Palace of Aranjuez.

The members of this order were the ones who began, in 1387, the construction of a villa for the recreational purposes of the masters. A few years later, approximately at the end of the XV century, the Catholics Kings began to attend this residence as a usual holiday place, a fact that continued with the next monarchs of the Houses of Hapsburgs and Bourbons.

In 1523, Aranjuez became royal property through the hands of pope Adriano VI in favor of Emperor Carlos V, awarded with the designation of Grand Master of the Order of Santiago; although previously the meadow of Aranjuez was already in the Catholics Kings hands, due to the intercession of Isabel the Catholic in favor of her husband Fernando [1], becoming the Master of Spanish Chivalry Orders.

Under the supervision of Felipe II, the construction of a new palace began, whose traces were first order to Juan Bautista de Toledo, and after his death, was taken by Juan de Herrera. This complex project stood in the same spot where it remained the old master house. Since the construction was carried out steadily, it allowed to continue using the old residence while the new one was being built: this situation made easier the royal family to attend Aranjuez to enjoy hunting and nature. This new location was built along the banks of Tajo river, surrounded by thick vegetation which, after invading the gardens, ended up giving an Italian appearance [2].

Felipe II and Juan Bautista de Toledo made Aranjuez acquire more importance, and therefore a new palace was built, which was adapted to the new Italianate tastes of the moment, as well as the environment acquiring outstanding importance for the first time in a royal resident [3].

With this new planning, the rivers got a new point of view which went from more hedonistic activities to the most industrial, and because of that they made the channels of the rivers adequate, adapting them to the needs required according to their future use.

To be able to carry out all these new interventions, it was first needed a spatial study of Aranjuez, which was concluded on 1544 [4]; this intervention was critical to expand the boundaries of the pasture through the purchase of the annexed land to the royal property.

During the reign of Carlos $\mathrm{V}$ there were built several elements that would be of a significant importance for the later engineering tasks of his son Felipe II [5]. One of these initial elements was the Embocador dam, built around 1535, by the Italian Francisco Sitoni. From here derived two ditches, Sotomayor and Rebollo, whose flows were destined to the irrigation of Aranjuez, influencing the agriculture development of the area and supplying 
water for the fonts of the gardens. It was on this Embocador Dam, where it became to be rethought the system of the pipes extending their borders towards Rebollo, however this didn't happen until the year 1561 and 1562 in order to make the water accessible to the nearby towns.

Under the orders of Carlos V there were built several dams as the Valdajos dam in 1530, where it originated the irrigation channel of Colmenar, feeding water to the palace; from there it emerged a ditch which was used to improve the irrigation channels and ensure the development of the area. This was a complicated project that started with the Valdajos dam, whose reconstruction work began in 1553, and two decades after those actions, with the aim of achieving the levelling began, which were executed under the supervision of Juan de Herrera within the years 1571 and 1572, and continued until 1579; once these works were completed they began with the planning of the irrigation system, which began afterwards.

In the 1550s new dams were built, such as San Remondo (1557), the dam of Requena (1559) and the repair of the dam of Embocador. The landscape water system of Aranjuez was composed by a complex system of waterworks that consisted on dams, dikes and panels for the control and the levelling of the water flow of the channel network. The control of the rivers was based on a set of contention dikes that regulated the flowing of water to the area of Island garden and the Palace, thus the waters came gentler to the residential area of the Royal Site.

The renovation ideas that Felipe II had for Aranjuez did not consist on just a wide network of irrigation, but sought to create an extensive network of navigable canals that extended from Madrid to Lisbon. These new plans took place in 1561 and involved the contrition of new dams and locks that would help save the unevenness of the land; on the first project, they planned to make navigable one part of the Tajo river close to the Royal Palace. One year later, this project was expanded in order to get together Aranjuez and Toledo across the Tajo river; and two decades later, the project was extended until another part of the Jarama river was navigable. But the plans of Felipe II were much more ambitious, he intended to get to Lisbon navigating these two rivers. All these reforms had a recreational background, such as fishing, strolling on the banks of the river and the naumachia, despite the claims for its future use it did not stop just there, the intention was to be able to use these rivers as a shipping routes communicating the center of the mainland with the south and the Atlantic Ocean.

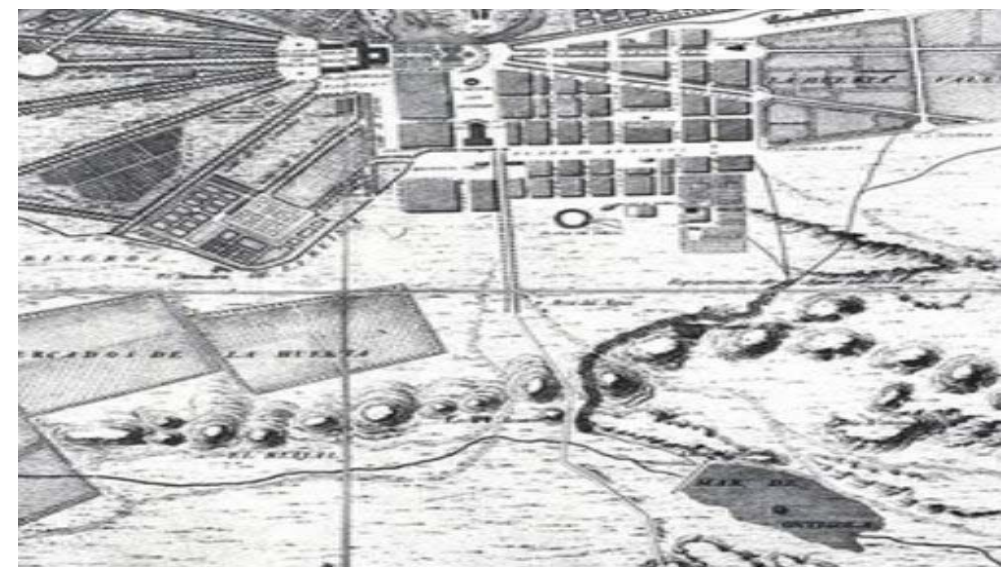

Figure 1: Map of Aranjuez. Ontigona Sea, Domingo Aguirre, 1775. 
In order to be able to carry out nautical leisure activities, Felipe II chose Ontigona dam, located five kilometers away from the Royal Palace of Aranjuez. This dam was a hydraulic engineering, construction from the 16th century. While they were trying to look for navigable parts of the river; and it took three quarters of century to be built. In order to make his naumachia, Felipe II chose the area of Ontigola to performed as it was an area with multiple points were water flowed, an essential element for this purpose [6].

The first commandment for the realization of the task took place on 17th May 1552, beginning with the creation of a big lagoon at Ontigola which brook along with other two or three smaller ones directed to Ciruelos to attract the birds to the haughtiness. Due to different problems, the beginning of the implementation was delayed until they finished with the construction of more urgent works. Once stared, it was supervised by masters Alonso de Covarrubias and Luis de Vega, until the end of 1560, when the project management changed to Juan Bautista de Toledo and a Flemish builder specialized in dikes.

In 1562 the worker directors changed again, and then Juan de Castro and Adrian Van del Mulse, a Flemish with wide experience in the construction of dikes, were in charge of the project; they were supervising the construction of containment dikes and the adequacy of Ontigola brook for the building of the dam [7].

At the beginning of 1563 it was decided the dam would consist on two stone walls separated by an embankment; In July the same year, the monarch commanded to check the water tightness of the Project, and after the trial, fish and swans were taken to the dam, under the monarch's command, as well as the construction of artificial islands inside the dam. During the following year, the works didn't suffer any interruption, and by 1565 , the dam was finished, when Felipe II ordered to empty it lightly, in order to make the islands stand out and the construction of ledges in the topping off the dam.

In March of the same year, a crack appeared on top of the dam embankment, making the wall collapse, but this was sorted out building several buttresses, as master Francisco Sánchez aimed initially, and approved by Juan Bautista de Toledo, as well as the implementation of some drain holes in order to lighten the wall pressure. Once again, in 1567, the dam was filled up, and by the beginning of the year, a rift reappeared again and solved, however in June, the wall collapsed where there were no buttresses. The solution to this recurring problem was the construction of a few more buttresses, in order to strengthen the walls, as it had already been done in 1565 .

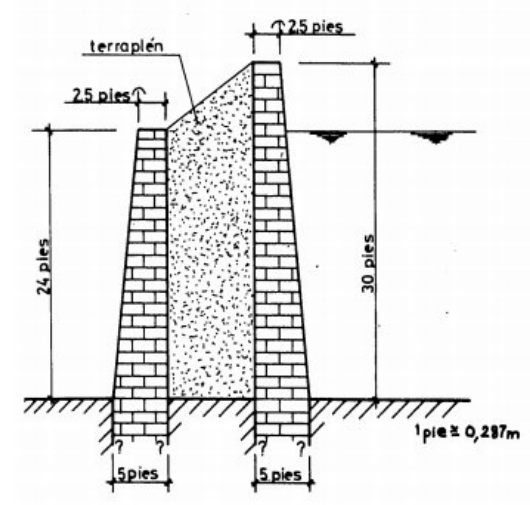

Figure 2: Detail of the design of the Ontigola dam [7]. 


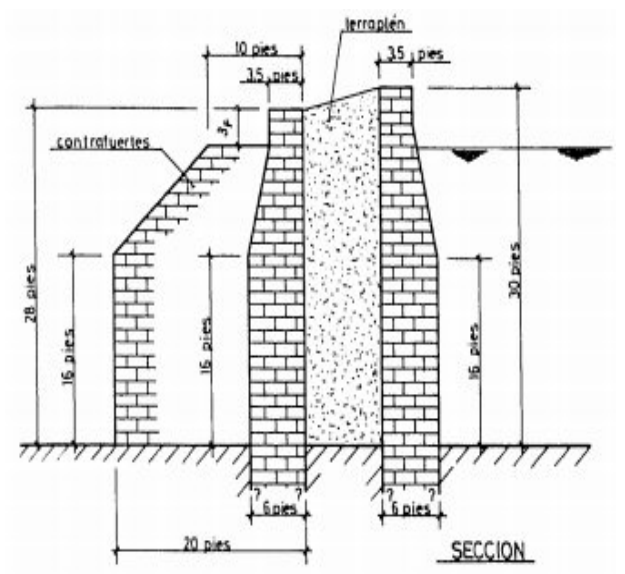

Figure 3: 2nd Project with buttresses of the Dam of after the collapse of the front wall. March 1565, Juan Bautista de Toledo [7].

During the next decade of the century XVI, Felipe the Second commanded to enhance the height of the dam's parapet. At the end of 1572, the dam was already finished, and after a year, only the watercourses and spillways were left to do. Finally, Ontigola dam reached a depth of seven meters plus one.

The Ontigola Sea, as well as the dam also known with the same name, was formed by several artificial islands crowned with gazebos which were visible from the naumachia and the tournaments that were performed. The central island had a pavilion and a pier with handrails along the way where gondolas arrived and moor, which were used for sailing on this artificial sea. These activities navigations related were completed with the fishing carried out from these vessels or sea tours [8].

During the reign of Felipe IV and Carlos II it was the feast of the cliffs that consisted on putting cages with bulls inside at the top of the hill. When the cage was opened, they slid down through the slippery hills till finish in the water, where they played with them from the boats, guiding them to the central arbor, where the monarchs were waiting to conclude the feast with an harquebus [9].

The construction of dams, dikes, waterways, or artificial islands gave as a result the total or partial modification of the territory surrounding Aranjuez.

These changes were initially intended for watering the gardens of the Royal Palace and for the supply of the fonts; after the use of these variations of natural watercourses of the rivers they were either for commercial use, for navigation and for the carriage of materials as well as for the use of flour mills in the area. To conclude, the main transformation inside the area of Aranjuez was the dam or sea of Ontigola, completely destined for recreation with the naumachia, fishing activities and walks [10].

All the small interventions that were carried out in the surroundings of Aranjuez had as main element the Royal Palace; the alterations in the channel of the nearby rivers were carried out to prevent them to overflow and affect the building; for this reason, a set of dams were built that maintained a regular flow.

But the greatest alteration of the environment of Aranjuez was the creation of the dam of Ontigola. The reconstructed design and construction of this engineering work gave the place it's final transformation of the environment of the area forever. With this we can say 
that Tajo and Jarama river were the two articulating arteries of the south of Madrid.

\section{CÓRDOBA AND THE GUADALQUIVIR}

Throughout history, Guadalquivir river has changed its name (Baetis, Tartessos, Tharsis, Narh Qurtuba, Wadalkabir, etc.), and has had its course rectified modified by the construction of dams and reservoirs in order to help preventing floods [6]. However, its reality as the backbone of the space between Sierra Morena and the hills of the Andalusian countryside, has remained unchanged [11].

The fertility of the land, the softness of the topography and the use of Guadalquivir river as a transport engine, have made its banks the preferred place to settle. The presence of settlements on the banks of the river is well documented both by the descriptions of different historical chroniclers and by the discoveries that archaeology has made since the last century.

Among all these nods of population, Córdoba dominated from the right bank the whole valley, just at the point where Guadalquivir ceases to be navigable. This position, therefore, has historically conferred the city the ability to easily dominate the confluence of the major communication routes of the south of the Iberian Peninsula. This made possible to control the goods and people that were transported between the two halves of the channel and the option of being the first population to receive commercial goods [12].

The origin of Córdoba goes back (according to the data obtained by the archaeological investigation) to the third millennium BC. This settlement would, in turn, have been a river port right at the crossroads of what later would have been Bética and Hispania Citerior [13].

By the Roman times, the settlement changed places and it was located in a nearest plain. This position made possible for the roman Córdoba to become the gateway and from both the communications and commerce that were carried out through the navigable course of the Guadalquivir [14].

The prominence of the river remained unchanged throughout the Middle Ages and the XVI century [16]. To the functions of transport and communication already mentioned, it would be added a fundamental one for the development of Córdoba: the industrial one. The driving force of water played a decisive role in the economic growth of the city, as in the river bedpans, were located water mills, tanneries and mills: in the neighborhoods close to the banks, most of the commerce and handicrafts of the city were located [17].

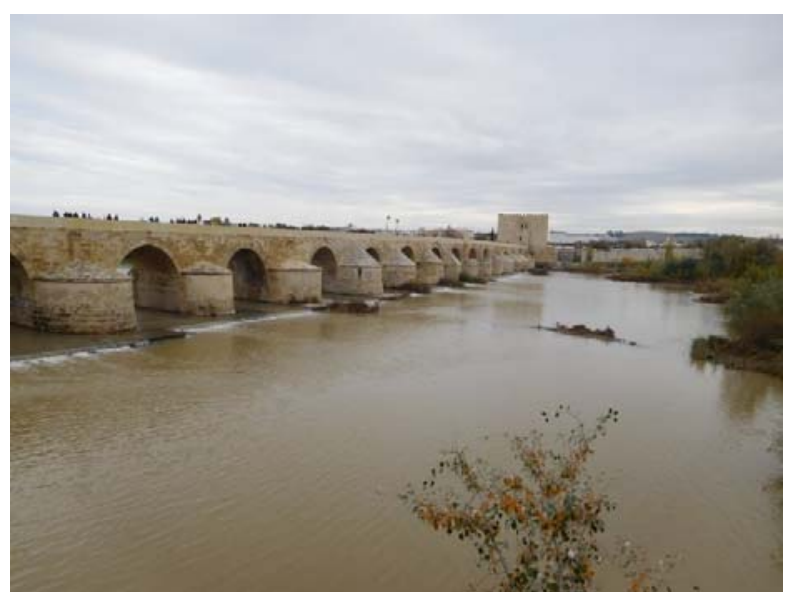

Figure 4: Roman bridge of Córdoba. Heavily modified throughout history. 
There are continuous references to small industry, both in medieval texts and in the documentation of the twelfth and thirteenth centuries. They stood out above all the fullers, that used the force of the water to elaborate the famous cloths in Córdoba wool [18].

When Fernando III took the city in 1236, the river mills became property of the curia, nobility and religious and military orders who had actively participated in the Reconquista. The new population kept in working in the inherited building, making possible its historical continuity. Therefore, the continuous use of these productive techniques over the centuries made possible for these architectural elements to remain more or less immutable up to the present time, being an indissoluble part of the current image of the city [19].

Next to the roman bridge four of these mills can be seen, although its original disposition has been modified throughout the centuries:

The flour mill of Albolafia, from medieval period, influenced the transformation of the flow of the river; the flour mill of Enmedio, medieval, which maintained its work until the first third of century XX; the Molino del Pápalo, also flour mill and medieval origin, which was in a state of ruin at the beginning of the 20th century; and, finally, the mill of San Antonio probably raised in the eighteenth century [20].

The relationship of dependence among of Córdoba and Guadalquivir River was diluted in the late XVI century, when the industrial activities associated with the river began to decline [21]. The mills were reformed and expanded to meet the demands of each stage, until the XX century many of these elements were reconverted into hydroelectric stations while others were abandoned.

The urban rethinking that this brought with it, as well as the continuous floods of the river and the consequent floods of its banks caused the center of activity to move away from the channel to the north of the city [22]. However, Córdoba continued to maintain its activity on the right bank, attached to the river, transforming the previous industrial activity to places of recreation and relaxation [23]. The first interventions in this sense were made in the XVI century with the project of the mayor Francisco Zapata de Cisneros to flatten all the ground from the mill of Albolafia to the door of the arches building the Alameda [24]. This walk along the river is referenced in multiple historical texts, as a place frequented by Cordoban society especially in the hot summer nights [25].

In the XIX century, urban expansions and reforms moved these walks to the northwest of the city, eliminating the recreational nature of the river margins in a definitive way. In

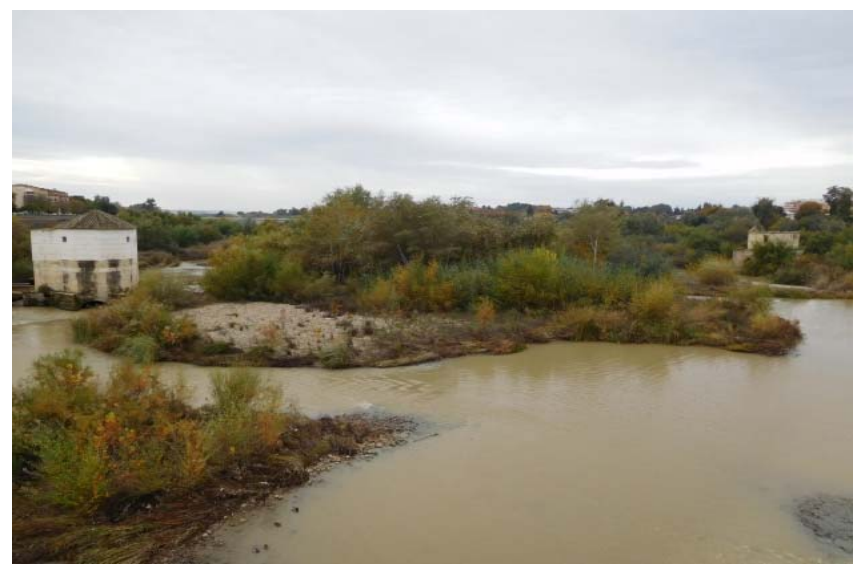

Figure 5: Flour mills of the riverbed of the Guadalquivir within the city of Córdoba. 
this sense, Guadalquivir river went from being the fundamental axis of the city to a marginal place in which empty spaces and buildings of an increasingly ruinous aspect took place [26]. The urbanistic actions at the beginning of the XX century helped to turn it into a physical barrier, a limit of the city, with plans and projects that turned their backs on the channel and impoverished the fluvial landscape of Córdoba.

In the 1990s the attempt to recover the riverbanks as part of the city began, prompting local governments to draw up a series of strategies to rescue social, environmental, landscape and historical values [27] of Guadalquivir River and its environment designed to integrate this residual space in a fundamental place for the identity of the city. It is contemplated the necessity of recovering the characteristic values of that singular environment, its linear character following the flow of the river. At present, this global recovery project has made possible to reform several mills among the eleven that are within the city. The new uses for these spaces are related to environmental and cultural education, turning them into in museums and into ornithological observatories [28]. This transformation has facilitated the assessment of these architectonic elements of great patrimonial value.

In turn, the decision to pedestrianize the right bank - recovering the paseo de la Ribera and to build new recreational spaces on the left bank has contributed to recover the banks as places of leisure and recreation, understanding the river as an element of connection to be capable of creating city; the linearity of the river is reinforced, therefore, through the promenade and urban spaces.

In this way, the process of integrating the river and its elements into the urban fabric reach its highest point: at the capacity of the Guadalquivir is studied as a unique articulating element. This fact does not suppose the loss of its condition as a natural element, since on the other hand it has also worked on the maintenance of the ecosystem of the flow itself, with its sandy islands, its riverside forests and its fauna.

Little by little Córdoba is recovering the river landscape of the Guadalquivir, incorporating historical buildings that until now remained in oblivion [29]. The strategic plans seek to combine tourism, cultural and social factors through the enjoyment and knowledge of the material and immaterial treasure that over the centuries brought together the privileged area of the river [30].

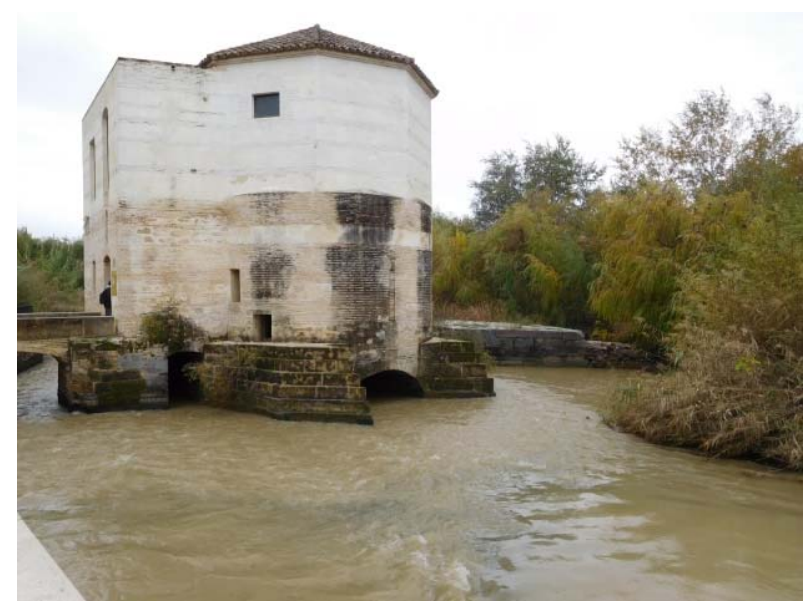

Figure 6: San Antonio Mill. 


\section{CONCLUSIONS}

For all of the above, we can state that the techniques of exploitation and occupation of the river and its flow are connected with the transfer and maintenance of knowledge and best practices over the centuries, regardless the culture present at any given time.

Their permanence over time is due to their excellent suitability and the specific characteristics of the river and the city, which made their translation viable to the present day.

This fact represents an exceptional form of relation between architecture and nature, based on the diversity of situations that have been inherited from the different historical stages and their corresponding influences. They also respond to the different needs of the typologies of settlements established in its banks and the uses that they demanded.

The two case studies dealt with two archetypes of opposing urban settlements and the evolution of the relationship they have had with the channel according to their intrinsic characteristics: on the one hand, Aranjuez and the court, with a mainly playful and limited enjoyment in the space on the banks of the Tajo and the Jarama; and on the other hand Córdoba and the Guadalquivir, whose mutual dependence has been transformed over the centuries depending on the needs of the population in each historical moment.

Irrespective of the differentiated aspects of both cases, we can say that rivers have a relevant role in their immediate environment, since they favor the emergence of inhabited settlements that depend on the waters of their channels for fishing, agriculture, industry and leisure. In addition, the river landscape itself, give exceptional natural and historical values to these privileged places.

For all of this we believe that the correct transformation and continuity of these patrimonial and natural values inevitably happen to take into account the following aspects:

- The realization of promenades, public spaces and gardens along the banks

- Recovery of water quality and decontamination of the same

- The correct knowledge and interpretation of historical facts that have resulted in the present situation

- The landscape assessment of the river and its banks

- The recovery of the natural surroundings of the banks of the river

- To re-contemplate the river channel as the powerful urban and territorial structural axis that has been throughout history

\section{REFERENCES}

[1] López y Malta, C. \& Álvarez de Quindós, J.A., Historia descriptiva del Real Sitio de Aranjuez, escrita en 1868 sobre lo que escribió en 1804 D. Juan Álvarez de Quindós, Doce calles: Aranjuez, D.L. España, 1988.

[2] Álvarez de Quindós, J.A., Descripción histórica Del Real Bosque y Casa de Aranjuez, Aranjuez, Ayuntamiento D.L. España, 1982.

[3] Merlos Romero, M.M., Arquitectura palaciega y de recreo, la presencia de las clases privilegiadas en Aranjuez en el siglo XIX, Goya: Revista de arte, (256), pp. 221-229, 1997.

[4] García Grinda, J.L., Guía de Aranjuez, el paisaje construido. Biblioteca Virtual de la Comunidad de Madrid: Madrid, 2008.

[5] Barja de Quiroga, J., Bibliografía Del Real Sitio de Aranjuez: el Real Sitio de Aranjuez y el arte cortesano del siglo XVIII, salas de exposición del Palacio Real de Aranjuez, pp. 141-148, 1987. 
[6] Luengo Añon, A., Aranjuez, utopía y realidad. La construcción de un paisaje. Doce calles: Madrid, 2008.

[7] García Tapia, N. \& Ribera Blanco, J., La presa de Ontigola y Felipe II. Revista de Obras Públicas, 1985.

[8] Mar de Ontigola, Lista roja de Patrimonio de Hispania Nostra. Accessed on: 22 Mar. 2017.

[9] Merlos Romero, M.M., Aranjuez y Felipe II. Idea y forma de un Real Sitio, Dirección General de Patrimonio de la Consejería de Educación y Cultura de la Comunidad de Madrid: Madrid, 1998.

[10] Reserva natural de El Regajal-Mar de Ontigola, Espacios protegidos de la Comunidad de Madrid. Accessed on: 22 Mar. 2017.

[11] Zoido, F., Territorios y paisajes del Guadalquivir. Madrid, Brizzolis Arte en Gráficas, pp. 3-17, 2008.

[12] Vaquerizo, D., Ad Ripam Baetis: Corduba/Colonia Patricia Simulacrum Romae. Madrid, Brizzolis Arte en Gráficas, pp. 185-197, 2008.

[13] Murillo, J.F., Corduba: de la ciudad indígena a la ciudad romana, La ciudad en el mundo romano. Actas del XIV Congreso Internacional de Arqueología Clásica: Comunicaciones, 2, pp. 260-261, Tarragona, 1994.

[14] El Río Guadalquivir. Madrid, Brizzolis Arte en Gráficas, 2008.

[15] Zoido Naranjo, F. \& Fernández Salinas, V., Las relaciones ciudad-río en Andalucía. estudio de su evolución reciente a partir del planeamiento urbanístico y territorial. Sevilla, Universidad de Sevilla, 2005.

[16] Rodríguez, F.J., El Guadalquivir y su imagen en el siglo XIX: la construcción de un paisaje (1830-1862). Revista, 72, Instituto Andaluz de Patrimonio Histórico, pp. 4045, 2009.

[17] Acosta, G., El Guadalquivir, patrimonio territorial andaluz. Revista, 72, Instituto Andaluz de Patrimonio Histórico, pp. 40-45, 2009.

[18] Bejarano Escanilla, I., Poesía: naturaleza y paisaje. Paisaje y naturaleza en alAndalus. Consejería de Cultura de la Junta de Andalucía-Fundación El Legado Andalusí, pp. 115-138, 2004.

[19] Bonsor, G.E., Expedición arqueológica a lo largo del Guadalquivir. Écija, Gráficas Sol, 1989.

[20] Cabrera, E., Córdoba y su río en la Edad Media. El Pregonero. Complemento del diario Córdoba, 83, p. 5, 1990.

[21] Cabrera, E., Abdarrahmán III y su época. Córdoba, Caja Provincial de Ahorros, 1991.

[22] Córdoba de la Llave, R., Molinos y batanes de la Córdoba medieval. Ifigea, IX. Universidad de Córdoba, pp. 31-56, 1993.

[23] Cosano, F., Iconografía de Córdoba. Córdoba, Cajasur, 1999.

[24] Daroca Bruño, F., Guía de Arquitectura de Córdoba. Córdoba, Colegio Oficial de Arquitectos de Córdoba y Consejería de Obras Públicas y Transportes de la Junta de Andalucía, 2003.

[25] García Mercadal, J., Viajes de extranjeros por España y Portugal. Salamanca, Junta de Castilla y León, 1999.

[26] García Verdugo, F. \& Martín López, C., Cartografía y Fotografía de un siglo de urbanismo en Córdoba 1851-1958. Córdoba, Gerencia de Urbanismo, 1994.

[27] Gwynne, P., El Guadalquivir. Su personalidad y sus gentes. Sevilla, Renacimiento, 2006. 
[28] Lévi-Provençal, Córdoba en el siglo X. Historia de España, V, Madrid, pp. 227-255, 1957.

[29] Ramírez de Arellano y Gutiérrez, T., Paseos por Córdoba, o sea apuntes para su historia. Córdoba, León, Everest y Librería Luque, 1973.

[30] Ramírez de las Casas Deza, L.M., Corografía Histórico Estadística de la Provincia de Córdoba. Córdoba, Facsímil, 1986. 